\title{
The Assessment of Deforestation Impact Towards Microclimate and Environment in Ilorin, Nigeria
}

\author{
Toluwalope Mubo Agaja*, Elisha Ademola Adeleke, Enekole Esther Adeniyi, Precious \\ Temilade Afolayan \\ Department of Geography and Environmental Management, Faculty of Business and Social \\ Sciences, University of Ilorin, P.M.B. 1515, Ilorin, Nigeria \\ *Corresponding Author : agaja.tm@unilorin.edu.ng
}

Received 25 February 2020/ Revised 6 October 2020 / Accepted 10 October 2020/ Published 30

December 2020

\begin{abstract}
Nigeria obtains high rate of deforestation with a loss of about 60 percent of its primary forests between 2000 and 2005 as a result of logging, subsistence agriculture,wood exploitation, and urban expansion. This research assessed the level of deforestation and how it has affected Ilorin's microclimate and the environments. The specific objectives of this study were assessing the relationship that occurs between deforestation and microclimate, examining deforestation and the impact it has within the study area of microclimate, and forecasting the microclimate within the study area by the year 2030. The statistical tools engaged were both descriptive (mean, frequency distribution table and, bar charts) and inferential statistics (multiple regression analysis). The research indicated that there is a significant relationship between deforestation with $\mathrm{r}^{2}$ variables of 0.888 for maximum temperature, 0.201 for minimum temperature, 0.997 for precipitation, 0.43 for solar output, -0.797 and 0.873 for evapotranspiration and relative humidity respectively and Ilorin's microclimate. The study concludes that deforestation greatly influences the microclimate of Ilorin and occurs due to human's anthropogenic activities. Deforestation has also led to climate change.
\end{abstract}

Keywords: Deforestation; Climate; Micro-climate; Vegetation Cover

\section{Introduction}

Human's relation with the environment has transcended through ages. Although, the human is the subject upon natural controls and events, the human acts as the dominant force establishing major long-term environmental challenges, one of which is forest degradation. For a long time, population increase has led to the removal of vegetation cover to meet the urban expansion demands. This has allowed for the thriving of deforestation without proper consideration towards the impact on the environment at large. Vegetation cover is major reservoirs for carbon sink, managing to regulate temperature as well as the layer of harmful gases concentration (greenhouse gases) within the atmosphere. However, deforestation 
increase has allowed the contiguity of more GHGs into the environment providing a microclimate that is heated up and unobligated. It is recognized that the more house/population grows, the more climatic variables appears into the environment.

In Ilorin, it is palpable that a major factor responsible for climatic variations is deforestation. Deforestation has been noticed to have accelerated in many countries with the tropical regions, such as Nigeria. Although reliable estimates are not available, it has been put at approximately 285,000 ha annually (Chakravarty et al., 2012). At this rate of deforestation, $50 \%$ of the country small forest land area had $10 \%$ of total land area being eliminated in 2015 (WWF, 2017).

Deforestation is the alteration of the forest to non-forested land conducted by the human. It occurs due to human demand for certain services which might be promoted for conversion or adjustment upon the land that is dominated by naturally growing trees into a land that suitable for the needs of the growing population (Kumari et al., 2019). Globally, tremendous pressure has been put on wood land settings as a result of deforestation and forest dilapidation. From 2010 until 2015, approximately 122.29 million hectares (Mha) of tree cover were disappeared (WRI, 2020). This number reached about 5\% of the total area covered by natural forests in 2010. Deforestation and other land utilization shifting are now considered as the second major anthropogenic source of Green House Gases (GHG) emissions, and a significant contributor towards climate change. A large proportion of the carbon dioxide $\left(\mathrm{CO}_{2}\right)$ is brought into to the atmosphere as the results of people activities that are being absorbed by trees and other vegetation which enhance to soothe the potential climate change impact (Milman, 2018). A great proportion of annual global greenhouse gas emissions ranging between 12 percent and 17 percent are the consequences of forests lost (WRI, 2010). A major threat and concern towards people and the environment is deforestation both in small cities or towns and the gobal world in general (WRI, 2020). It continues to occur at alarming rates. Hence, it contributes greatly to the ongoing loss of biodiversity and increases the emission of several gases leading to global warming.

A study performed for the Centre for International Forestry Research (CIFOR) in Congo Basin revealed that several causes could be identified as deforestation factors. The direct causes namely infrastructural development or agricultural expansion while the most striking cause is economic development or population expansion. Nevertheless, agriculture constitutes the major factor of deforestation (Tchatchou et al., 2015). Among some countries, Nigeria has the world's highest deforestation rate of primary forests (Daramola et al., 2015). 
Issues are brought by land tenure system and the growing population rate are identified as the major factors of deforestation ( $\mathrm{Su}$ et al., 2011). The driving forces of high deforestation rates are demographic, institutional, cultural, economic and technological policy (Adeleke et al., 2017). As the demand for land expansion is growing, forested areas are rapid to be depopulated in order to provide logs for community construction, and a host of other amenities they may establish within the environment (Daramola et al., 2015). These changes promote urban areas into hotter place than rural surroundings which is as a result of human's behavior that managing areas with warmer temperatures in the environment (USEPA, 2017). Therefore, the heat has a tendency to spread out to other parts of the city, that affecting the microclimate. Vegetation cover helps to absorb carbon within the atmosphere that acts as the carbon sinks. Due to logging, the vegetation cover is reduced in size leading the inclination of $\mathrm{CO}_{2}$ being attached and the increase in the $\mathrm{CO}_{2}$ in the environment that enhancing the higher surrounding temperature (Senior et al., 2018)

Forests circumstances are changing significantly throughout the world and currently driving the climate which results in an imbalance in water, energy, and carbon on the land surface (Li et al., 2016). There are three rationales to identify a solid relationship between forest/vegetation structure and microclimate. Firstly, the proportion of energy penetrating through to the soil is reduced as the plant canopies absorb, scatter and reflect back the solar radiation received. Secondly, plant canopies absorb momentum from the air and thus wind speed decreases with depth within the canopy. Hence this suppresses turbulent of air mixing by vegetation. Thirdly, the water vapour amount is strongly depending upon the air temperature (Hardwick et al, 2015).

An increase of bare surface indicates an escalation of the surface temperature and conversely affects water bodies, as the rate of evaporation increases that brings water to drive away towards the atmosphere in gaseous form. A study reported that satellite data showed that forest-covered area globally and above land temperatures are the results of forest losses directing towards deforestation zone suffering an increase of temperature variations (Cescatti, 2016; Chapman et al., 2020). Deforestation has increased the environment temperature as being compared to emissions comes from carbon dioxide under other anthropogenic activity. The urgent of identifying the relationship between forest cover change and the temperature has become very critical since the rate of forest loss continues to rise and as a result, a shift in the local climate becomes distinct (Odoemene, 2017). Urbanization, agricultural expansion and deforestation have affected climate temperature that indicating to deteriorate and a 
significant approach to mitigate the heat island effect is performing tree planting (Wolff et al., 2018).

Greenhouse gases are absorbed by trees and this stage plays a crucial part in reducing the risk on global heat. Therefore, enormous proportions of calamitous gases bump into the atmosphere will likely increase and hastening the severity of global warming (WWF, 2017). An environmental consequence that being examined upon this global forest change in terms of deforestation or afforestation is microclimate changes (Prevedello et al., 2019).

Several studies have attempted to assess deforestation and how it has affected several aspects of global climate (Daramola et al., 2015; Li et al., 2016; Prevedello et al., 2019; Kumari et al., 2019; Wolff et al., 2018). In this term of study, there are limited studies concerned about microclimate and how deforestation has greatly forced it. The high rate of changes occurred in Ilorin in terms of land-use shifting from forested land to a construction area is distressing and needs for discretion. As a result, there is necessary to fathom the microclimate, as it deals with the domestic weather conditions upon study area and a swift change could occur as a result of anthropogenic activities that deforestation is a major one. Therefore, the aims of this study were to examine deforestation and the impact towards the micro-climate of the study area, to assess the relationship between deforestation and microclimate, to predict the rate of deforestation by the year 2030 and the impact of the microclimate towards study area.

\section{Methods}

Ilorin is located between latitudes $8^{\circ} 24^{\prime}$ and $8^{\circ} 36^{\prime}$ North of the equator with longitudes $4^{\circ} 10^{\prime}$ and $4^{\circ} 36^{\prime}$ East of the Greenwich meridian (Figure 1). Ilorin covers an area approximately $468 \mathrm{~km}^{2}$. It is $200 \mathrm{~km}$ from Abeokuta, $512 \mathrm{~km}$ from Sokoto, $574 \mathrm{~km}$ from Calabar, 1,013 km from Maiduguri and $494 \mathrm{~km}$ from Aba. Ilorin experiences humid tropical climate characterized with 7 to 8 months of rainy seasons. The dry season starts in November and extends to February (Daramola et al., 2015). The total average of annual rainfall in Ilorin is $1200 \mathrm{~mm}$. Ilorin's temperature ranges between $34{ }^{\circ} \mathrm{C}$ to $37^{\circ} \mathrm{C}$ from February to April, while months between November to January, the value ranges from $33{ }^{\circ} \mathrm{C}$ to $35^{\circ} \mathrm{C}$ (Ajadi et al., 2016). The soil in Ilorin is Ferruginous in nature (Iroye, 2017). This soil is suitable for crops growing such as yam, cassava, maize, and etc. The land utilization of Ilorin for some years back were primarily agriculture and forested areas with small construction area (Ifabiyi\& Ashaolu, 2014). The emergence of urbanisation has brought the drop of forested areas quantity over time due to population growth. 


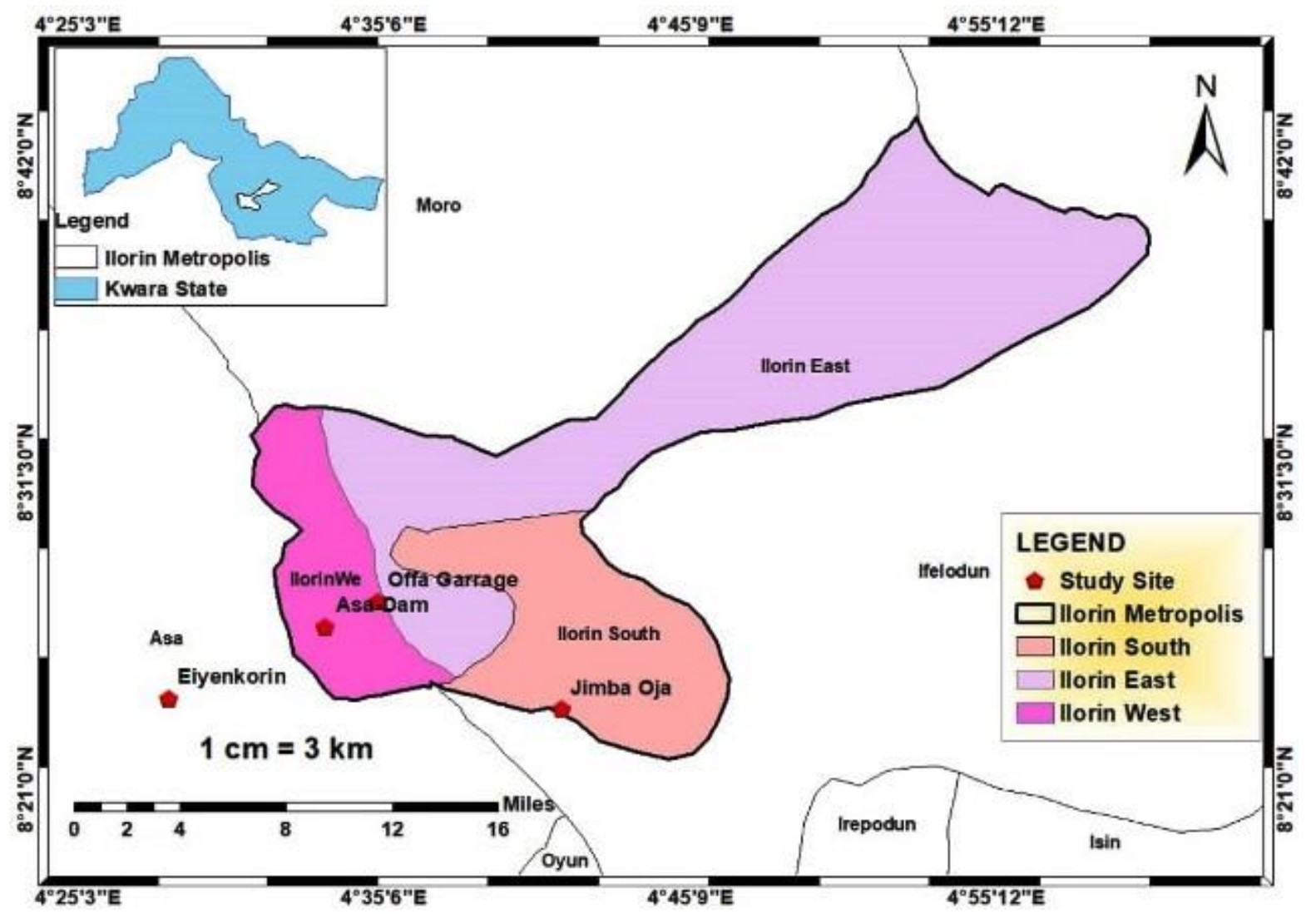

Figure 1. Ilorin City and Environs

The data used for this research was obtained from satellite images that demonstrating the rate of deforestation in Ilorin for about 30 years. The stage performed to collect the image information was Image Pre-processing. Under image processing, image normalization was conducted employing the histogram matching method. Image sub-setting was also engaged in which the image was clipped to the study area using the extract of mask tool in ArcGIS 10.5. Image pan-sharpening was utilized to improve the resolution of the multi-spectral images. Digital Number (DN) to Reflectance Conversion (RC), Image Classification and Feature Extraction (Train signatures, Image segmentation, Support vector machine classification) were also applied. In order to estimate evapotranspiration and interpolating climatic variables, SEBAL (Surface Energy Balance Algorithm for Land) model was utilized for the ArcGIS 10.5 environment to generate grid maps for climatic variables. Five satellite images were employed for this research. Each satellite image was captured at intervals. The intervals were between 1991-1996, 1997-2001, 2002-2006, 2007-2011 and 2012-2018. The satellite images were obtained from Landsat. The information regarding the extraction methods for satellite image data is presented in Table 1. 
Table 1. Type of Satellite Image Data Required and Source

\begin{tabular}{cccc}
\hline & Data & Resolution & Source \\
\hline \multirow{4}{*}{ Landsat } & TM 1991 & $60 \mathrm{~m}$ & \\
images & TM 1998 & $30 \mathrm{~m}$ & \\
& ETM+ 2003 & $30 \mathrm{~m} \mathrm{(15} \mathrm{m} \mathrm{panchromatic})$ & Global Land cover facility/ \\
& ETM+ 2013 & $15 \mathrm{~m} \mathrm{(10} \mathrm{m} \mathrm{panchromatic})$ & European Space Agency \\
& OLI 2018 & $15 \mathrm{~m} \mathrm{(10} \mathrm{m} \mathrm{panchromatic})$ & \\
\hline
\end{tabular}

Descriptive statistics were being used for presentation and summary were mean, frequency distribution tables and bar charts. In order to predict, this study employed the multiple regression analysis (Bender et al., 2007) to assess the effects of deforestation on microclimate by the year 2030 .

\section{Result and Discussion}

There was a gradual increase towards area covered by bare surface, although there was a decrease by $8.9 \%$ in 2003 . The gradual increase in the term of bare surface size on the land can be attributed to the increase of land acquisition for agriculture, some lands were left to fallow in order to store the nutrient for the next farming season. The size of construction areas grew rapidly from $8.62 \%$ in $1991-1996,12.95 \%$ in $1997-2001,13.98 \%$ in $2002-2006$ and 2007-2011 and 16.82\% in 2012- 2018 (Table 2 and Figure 2). This is in line with Dias et $a l .$, (2015) reported that evapotranspiration will be modified as a result of converting natural vegetation to bare surface and agriculture land. Then, it will manage to speculate the microclimate of the area being studied.

Table 2. Rate of Deforestation between 1991-2018

\begin{tabular}{lcccccccccc}
\hline & \multicolumn{10}{c}{ Year } \\
\cline { 2 - 11 } Land use $\left(\mathrm{Km}^{2}\right)$ & $1991-$ & $\%$ & $1997-$ & $\%$ & $2002-$ & $\%$ & $2007-$ & $\%$ & $2012-$ & $\%$ \\
& 1996 & & 2001 & $\%$ & 2006 & $\%$ & 2011 & \multicolumn{2}{c}{$\%$} & 2018 \\
\hline Bare Surface & 44.32 & 8.62 & 48.64 & 9.46 & 46.22 & 8.99 & 88.31 & 17.17 & 146.23 & 28.44 \\
Built up Areas & 43.97 & 8.55 & 66.60 & 12.95 & 66.48 & 12.93 & 71.87 & 13.98 & 86.48 & 16.82 \\
Forested Areas /Dense of & 134.71 & 26.20 & 128.60 & 25.01 & 120.51 & 23.43 & 124.11 & 24.13 & 40.64 & 7.90 \\
Vegetation & 238.95 & 46.47 & 194.18 & 37.76 & 126.39 & 24.58 & 101.40 & 19.72 & 111.94 & 21.77 \\
Grasslands/Farmland & 45.80 & 8.91 & 69.98 & 13.61 & 147.80 & 28.74 & 121.80 & 23.68 & 119.41 & 23.22 \\
Marshland/Streambed & 6.50 & 1.26 & 6.24 & 1.21 & 6.84 & 1.33 & 6.76 & 1.31 & 5.71 & 1.11 \\
Water Body & - & - & - & - & - & - & - & - & 3.86 & 0.75 \\
Cloud Cover & 514.25 & 100 & 514.25 & 100 & 514.25 & 100 & 514.25 & 100 & 514.25 & 100 \\
Total & & & & & & & & &
\end{tabular}




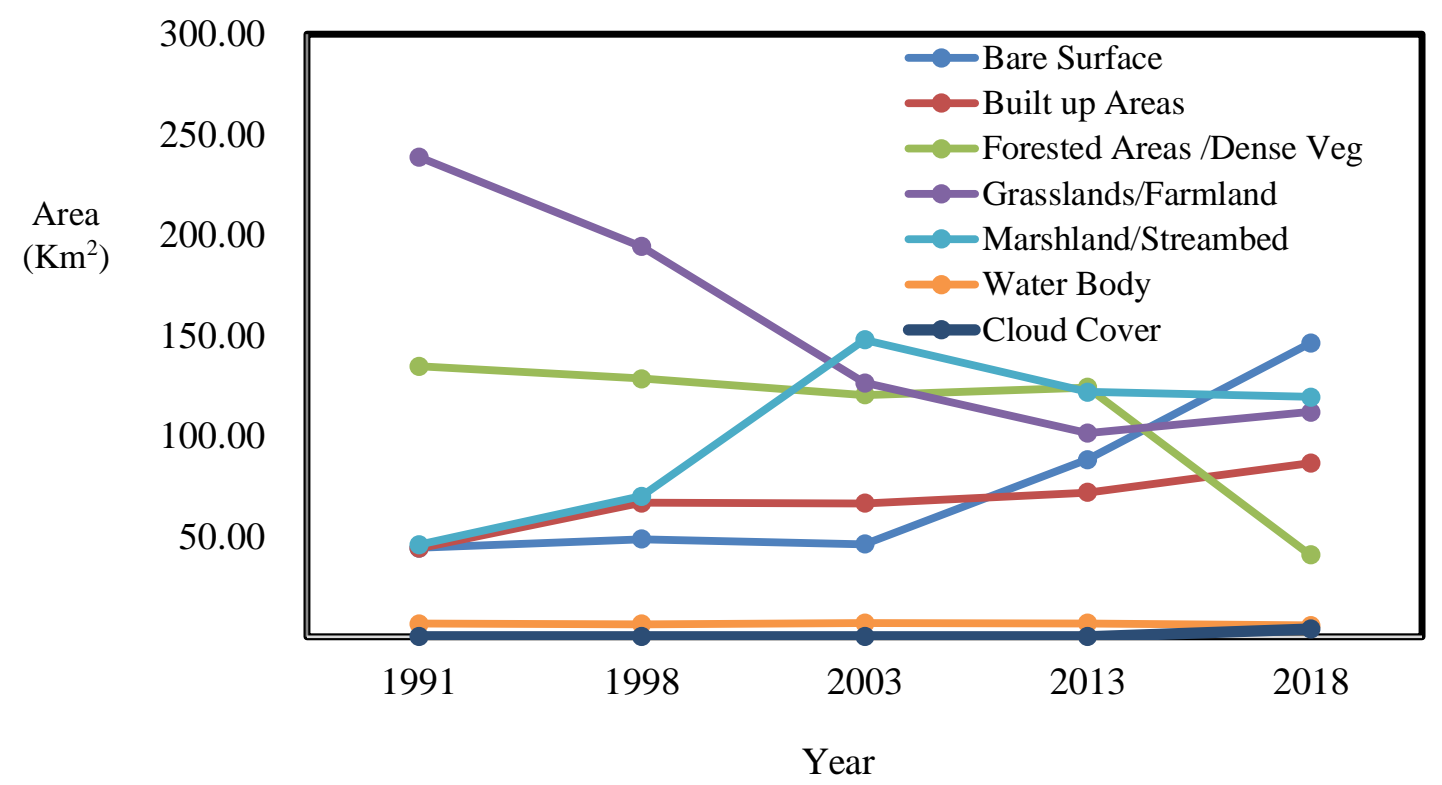

Figure 2. Land use in Ilorin

Forested areas covered about $126.20 \%$ in 1991 . There is a drastic reduction to $25.01 \%$ in $1998,23.43 \%$ in 2003, to a slight increase to $24.13 \%$ in 2013 and a solid decrease approximately to $7.90 \%$ in 2018 (Table 2 and Figure 2). The increase upon construction areas led to a reduction towards the amount of grassland and farm lands for agriculture in the year 1991 which was about $46.47 \%$ reduced to $37.76 \%$ in $1998,24.58 \%$ in $2003,19.72 \%$ in 2013 and rose to $21.77 \%$ in 2018 . The escalation shows in 2018 attributed to the sensitization of the people towards agricultural practice as a source of income. Furthermore, the size of water bodies has also declined over the years from $1.26 \%$ in 1991, to $1.21 \%$ in 1998, an increase in 2003 with $1.33 \%$, while 2013 and 2018 suffered a reduction in size with $1.31 \%$ and $1.11 \%$ respectively. The sizes of the construction areas and bare surfaces have increased leading to temperature escalation allowing the rise of heat upon the urban area (Table 2 and Figure 2). This occurs as the consequences of landscape changes. These results are supported by Fonge et al., (2019) indicated that the active conversion of forest land to farmland affects surrounding land utilization such as waterbodies and natural ecosystem. 


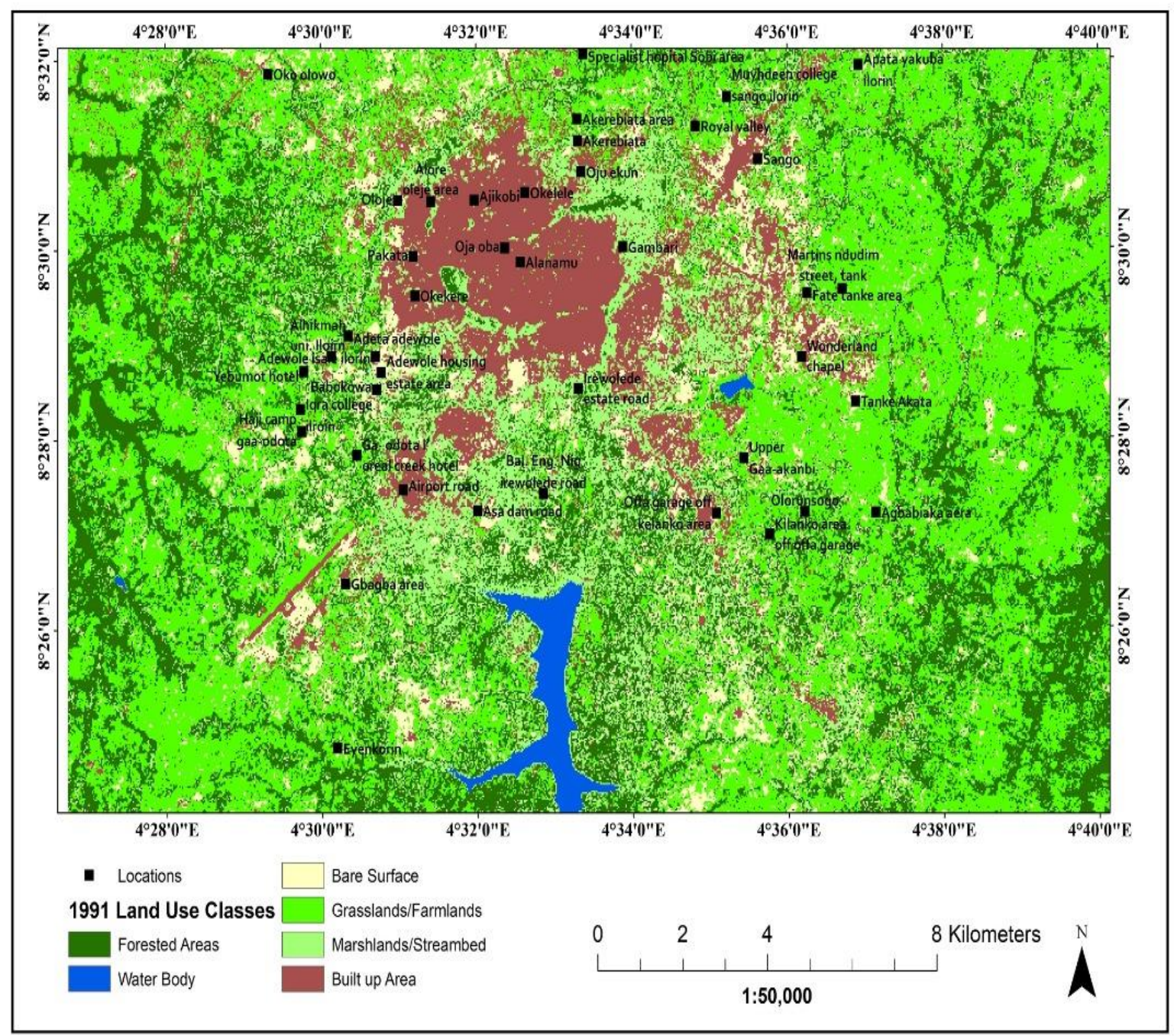

Figure 3. Rate of deforestation between 1991 -1996 in Ilorin, Kwara State, Nigeria.

Ilorin had smaller construction areas which were located at the centre of the city between 1991-1996. Despite the construction was gradually spreading into forested areas. The forested areas, marshlands, grasslands and farm floor still had much of the landmass (Figure 3). There was astraight increase in term of bare area sizeas well as construction spacewith 4.33 and 22.63 respectively. However, forested areas and grassland experienced a downward trend with 6.11 and 44.76 respectively (Figure 4). The demands for more construction areas escalate deforestation, means leading to lodging and displacement of the vegetative cover of the area. This result is supported by Tchatchou et al., (2015) that explained several reasons for deforestation occurred due to infrastructural development or agricultural expansion, economic development or population expansion. Nevertheless, agriculture constitutes the main reason for deforestation. 


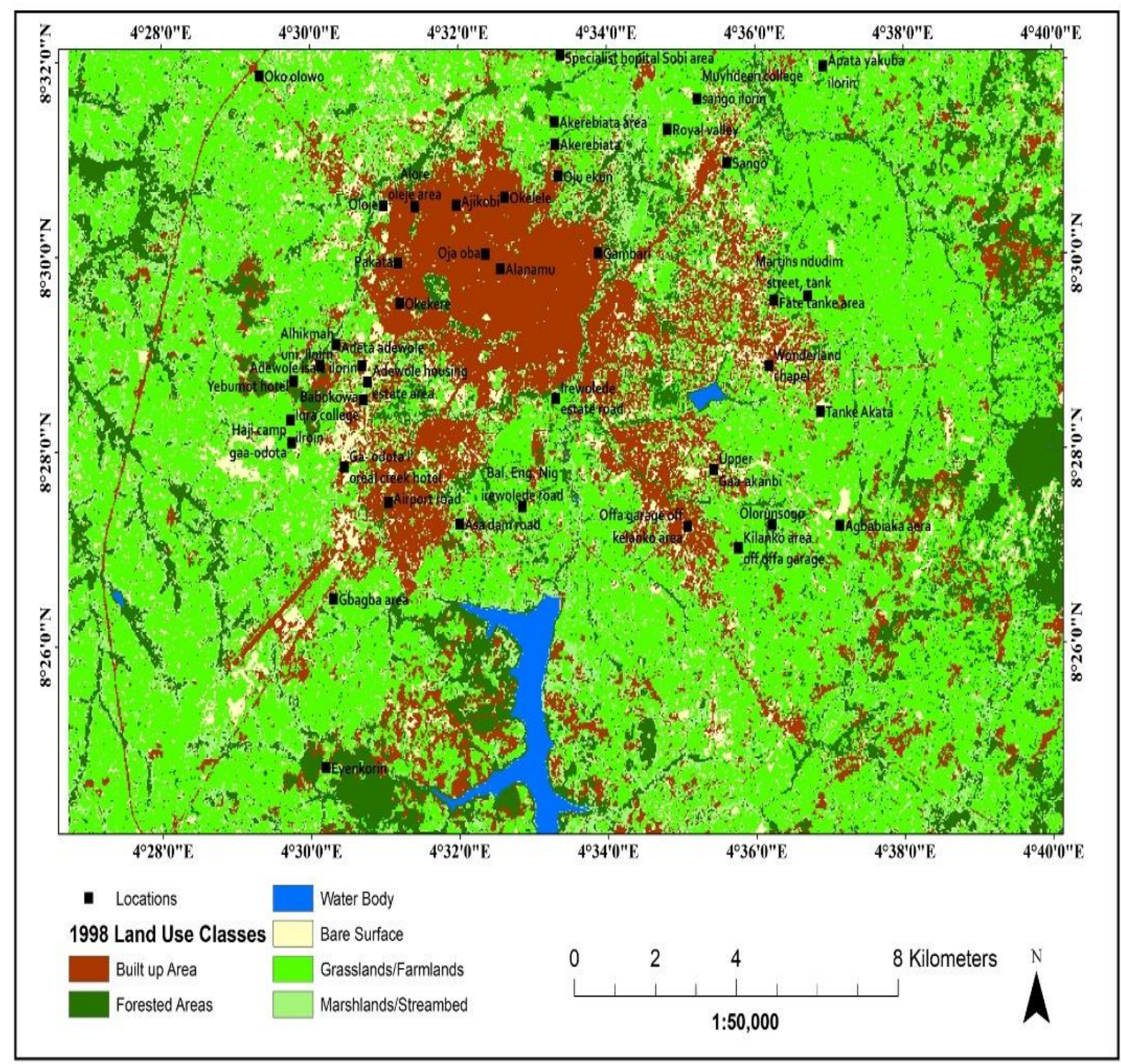

Figure 4. Land usage rate between 1998-2003 in Ilorin city, Kwara State, Nigeria

The construction areas have extended towards the forested areas, grasslands/farmlands, and marshlands/streambed. This extension due to the city expansion, as the population growsand industrial development. In addition, the bare surfaces have boostedand this might further lead to temperature escalation during this time (Figure 4). The changes of the size upon construction areas, bare surfaces, forested areas, grasslands, marshlands and water-bodies are almost negligible compared to Figure 4 in 1991. 


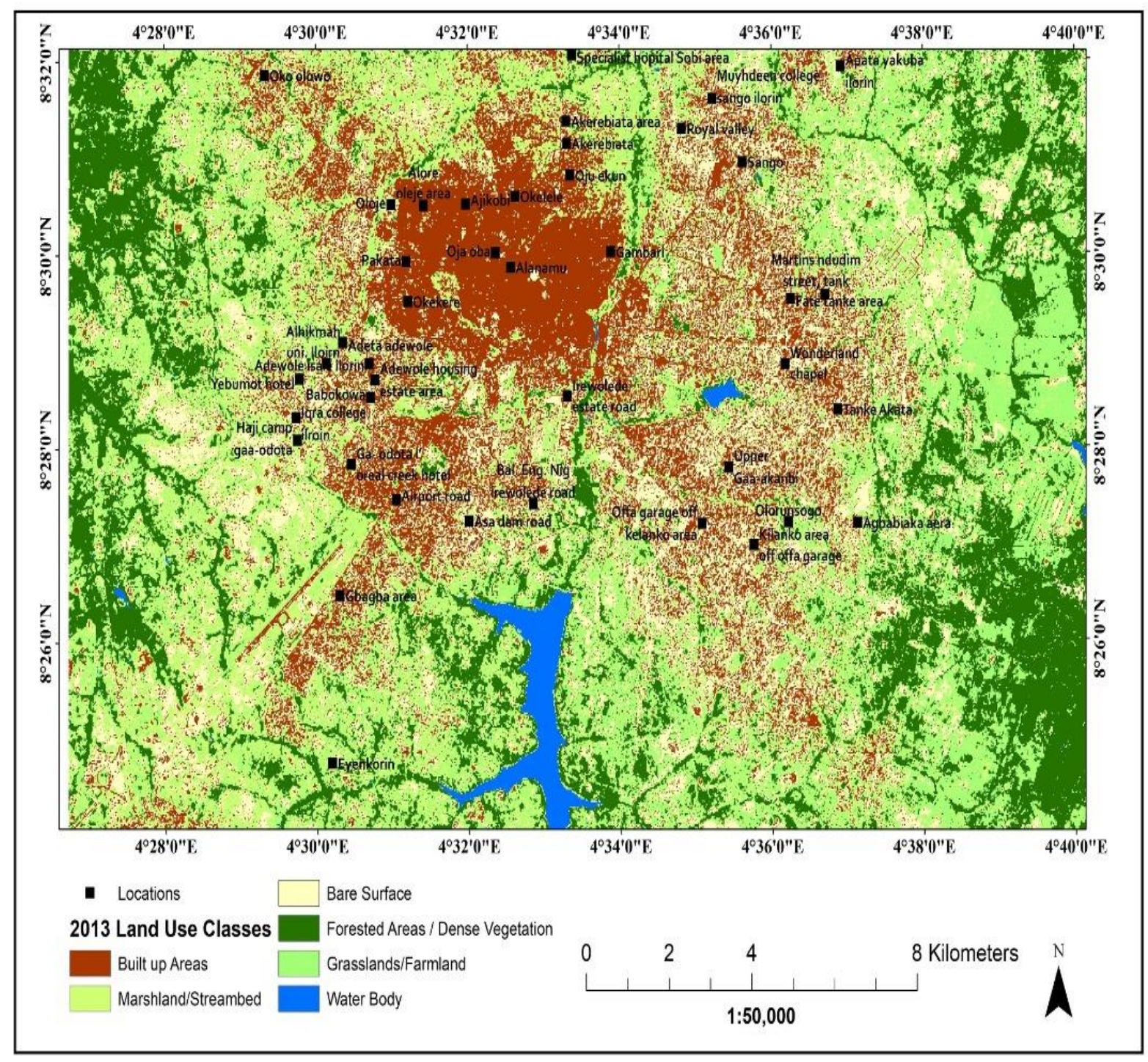

Figure 5. Land use rate between 2003-2013 in Ilorin city, Kwara State, Nigeria

The construction and the bare surface areas have absorbed deep into the forested areas by 2003-2013. Urbanization is a major factor, as the city population has greatly risen, more houses, schools and even commercial centres have been built (Figure 5). There is a significant increase in term of bare surface and construction areas with 42.09 and 5.38 respectively. The Forested surface also suffered a slight increase with 3.61, while grassland and marchland experienced a decrease with percentage with 25 and 26 respectively. This result is suitable with Daramola et al., (2015) reported that more the alteration of forested areas and vegetated surfaces shifting into construction areas and bare surface means the more of the land surface temperature will increase.

In addition, Urban areas become hotter than the rural areas due to such similar changes generating a distinctive area with warmer temperatures in the landscape (USEPA, 2017). Therefore, the heat tends to spread to other parts of the city, affecting its microclimate. 
Vegetation covers serve as carbon sinks, it assisting to reduce excessive warming of the surrounding environment (Nunes et al., 2020).

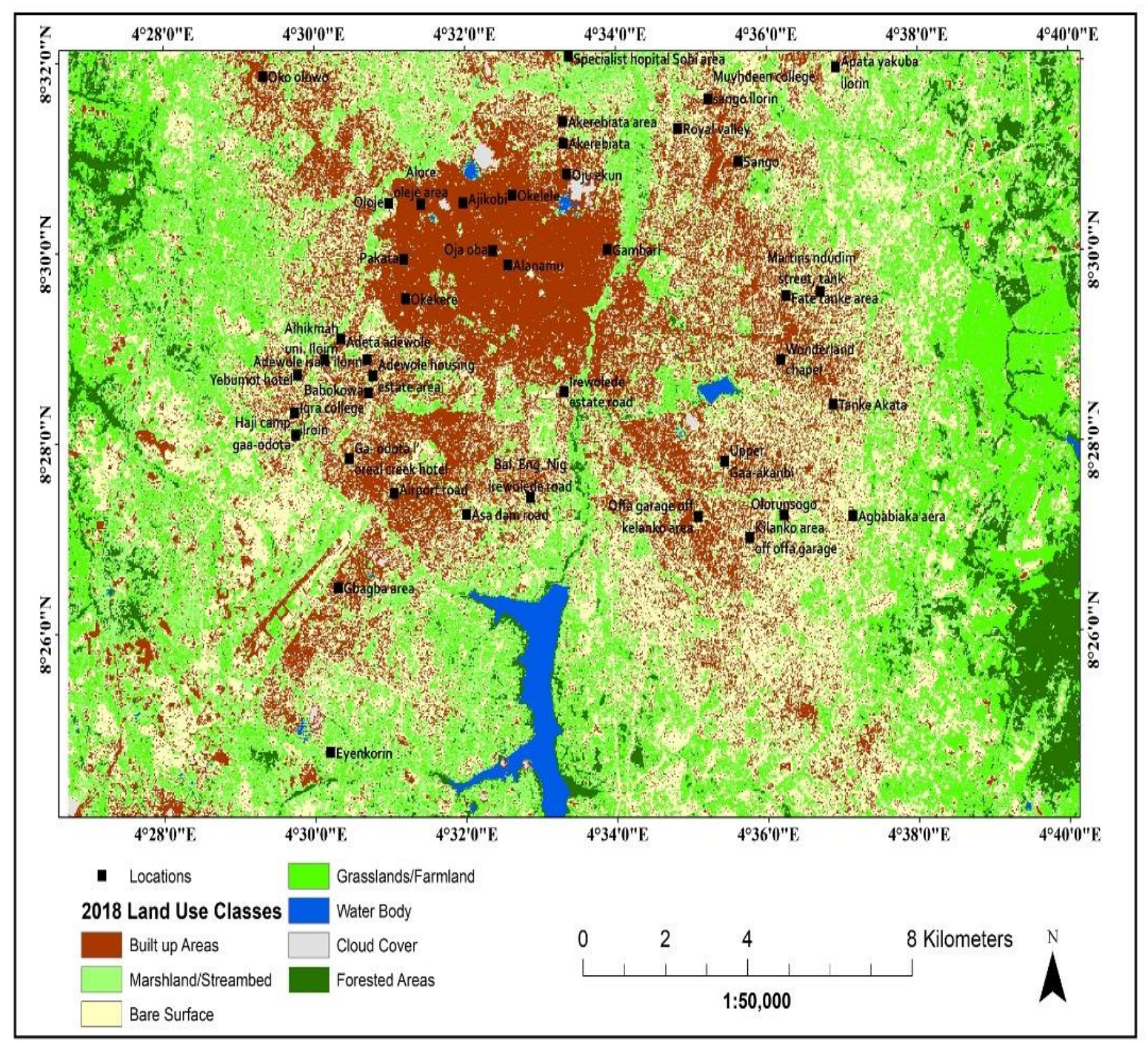

Figure 6. Rate of Deforestation between 2013-2018 in Ilorin city, Kwara State, Nigeria

There was a great expansion of the city, and only very few patches of forested areas, marshlands and grasslands were left as shown in Figure 6. Gradually, the construction areas and bare surfaces have expanded and currently still does. Bare surfaces and construction areas have increased greatly between 2013 and 2018 with 57.92 and 14.61. Forested areas have largely depreciated with the value of 83.47. These results support the findings of Adeleke et al., (2017) that the driving forces of high deforestation rates are demographic, institutional, cultural factors, economic and technological policy.

Multiple regression was utilized to predict the effects of deforestation towards micro climate by the year 2030 . The regression line equation $\mathrm{Y}=-19.26 \mathrm{x}+167.5$ was used to predict the rate of deforestation in the year 2030. Table 3 shows the model employed in 
predicting the micro climatic variables with the predicted rate of deforestation as the independent variable.

Table 3. Prediction of Micro climate variables

\begin{tabular}{|c|c|c|c|c|c|c|}
\hline \multicolumn{2}{|c|}{ Model } & \multicolumn{2}{|c|}{$\begin{array}{l}\text { Unstandardized } \\
\text { Coefficients }\end{array}$} & \multirow{2}{*}{$\begin{array}{l}\text { Standardized } \\
\text { Coefficients } \\
\text { Beta }\end{array}$} & \multirow[t]{2}{*}{$\mathrm{T}$} & \multirow[t]{2}{*}{ Sig. } \\
\hline & & $\mathrm{B}$ & Std. Error & & & \\
\hline \multirow{2}{*}{ Max Temp } & Constant & 29.993 & 4.432 & \multirow{2}{*}{.845} & 6.767 & .007 \\
\hline & Forest & .105 & .039 & & 2.734 & .072 \\
\hline \multirow{2}{*}{ Min Temp } & Constant & 21.123 & 2.240 & \multirow{2}{*}{0.215} & 9.430 & 0.03 \\
\hline & Forest & 0.007 & 0.019 & & 0.381 & 0.729 \\
\hline \multirow{2}{*}{ PPT } & Constant & 0.608 & 0.044 & \multirow{2}{*}{-0.991} & 13.948 & 0.001 \\
\hline & Forest & -0.005 & 0.000 & & -12.613 & 0.001 \\
\hline \multirow{2}{*}{ Wind } & Constant & 3.212 & 0.638 & \multirow[b]{2}{*}{-0.444} & 5.036 & 0.015 \\
\hline & Forest & -0.005 & 0.006 & & -0.858 & 0.454 \\
\hline \multirow{2}{*}{ R.Humidity } & Constant & 78.376 & 7.920 & \multirow{2}{*}{-0.889} & 9.898 & 0.002 \\
\hline & Forest & -0.232 & 0.069 & & -3.371 & 0.043 \\
\hline \multirow{2}{*}{ Solar Output } & Constant & 32.550 & 9.040 & \multirow{2}{*}{-0.518} & 3.601 & 0.037 \\
\hline & Forest & -0.082 & 0.079 & & -1.050 & 0.371 \\
\hline \multirow{2}{*}{ ET } & Constant & 25.214 & 5.788 & \multirow{2}{*}{0.744} & 4.356 & 0.022 \\
\hline & Forest & 0.097 & 0.050 & & 1.926 & 0.150 \\
\hline
\end{tabular}

Note : ET=Evapotranspiration; PPT = Precipitation; R. Humidity= Relative Humidity

As presented in Table 3, the model for predicting Maximum Temperature is given as $\mathrm{Y}=0.105 \mathrm{x}+29.993$, maximum temperature has a predictive increase rate of $0.105^{\circ} \mathrm{C}$ per annum. This implies that for each additional forest loss, the maximum temperature increases by $0.105^{\circ} \mathrm{C}$. This result is slightly different from Bright et al., (2017); Alkama \& Cescatti (2016); Chapman et al., (2018), that local and regional-scale impacts of tropical deforestation result in warmer surface temperatures and greater variation in temperatures.

Furthermore, the model for predicting Precipitation (PPT) is given as $\mathrm{Y}=-0.005 \mathrm{x}+$ 0.608 , PPT has a predictive decrease rate of $-0.005 \mathrm{~mm}$ per annum. Predicting wind speed is given as $\mathrm{Y}=-0.005 \mathrm{x}+3.212$ : wind speed has predictive decrease rate of $-0.005 \mathrm{~m} / \mathrm{s}$. This implies that for each additional forest loss, there is a decrease of $0.005 \mathrm{~m} / \mathrm{s}$ in wind speed. In addition, the model for predicting Relative humidity is given as $\mathrm{Y}=-0.232 \mathrm{x}+78.376$, Relative humidity has predictive decrease rate of $-0.232 \mathrm{kPa}$. This means that an addition of forest loss will lead to a decrease rate in relative humidity with $-0.232 \mathrm{kPa}$. Predicting solar output is given as $\mathrm{Y}=-0.082 \mathrm{x}+32.550$, solar output has predictive decrease rate of $8 \%$. This implies that there is an $8 \%$ decrease in solar output regarding an additional increase in deforestation. Furthermore, the model for predicting evapotranspiration is given as $\mathrm{Y}=$ $0.097 x+25.214$, evapotranspiration has predictive increase rate of $0.097 \mathrm{~mm}$ per annum. This implies that there will be an increase in evapotranspiration rates as a result of an increase 
in deforestation. The results for the climatic variables are supported by McAlpine et al., (2018) stated that there is a relationship between the local climate and deforestation as pronounced changes were noticed which were as high as $40 \%-75 \%$ loss of the forest and addition temperature increase to above $31{ }^{\circ} \mathrm{C}$ and more than $15 \%$ reduction in rainfall as a result of more than $15 \%$ forest loss since 1973 in Southeast Borneo. This occurred as the forested areas have been subjected to an open field.

Prevedello et al., (2019) also reported that land surface temperature (LST) might fluctuated due to deforestation or afforestation as open vegetation obtains a higher surface albedo compared to a cluster of trees. Thereby, increasing evapotranspiration (ET) and vagaries in the microclimate of the area being investigated. Also, the opening and withdrawing the canopy are the most pervasive impact upon logging as it rises solar radiation and air flow within under storey and the drop of evapotranspiration leading to an alteration of the forest's microclimate (Hardwick et al., 2015; Jucker et al., 2020; Senior et al., 2018).

Table 4. Predicted Variable for the year 2030

\begin{tabular}{ccccccccc}
\hline Date & Forested Areas & $\begin{array}{c}\text { Max Temp } \\
{ }^{\circ} \mathrm{C}\end{array}$ & $\begin{array}{c}\text { Min Temp } \\
{ }^{\circ} \mathrm{C}\end{array}$ & $\begin{array}{c}\text { PPT } \\
\mathrm{mm} / \mathrm{day}\end{array}$ & $\begin{array}{c}\text { Wind } \\
\mathrm{m} / \mathrm{s}\end{array}$ & $\begin{array}{c}\mathrm{RH} \\
\mathrm{kPa}\end{array}$ & $\begin{array}{c}\text { Solar } \\
\mathrm{MJ} / \mathrm{m} 2 . \mathrm{day}\end{array}$ & $\begin{array}{c}\text { ET } \\
\mathrm{mm} / \mathrm{day}\end{array}$ \\
\hline $3 / 5 / 2030$ & 63.6 & 36.8 & 21.6 & 0.29 & 2.90 & 63.6 & 27.3 & 31.4 \\
\hline
\end{tabular}

Note : ET=Evapotranspiration; PPT = Precipitation; RH = Relative Humidity

Table 4 presents the predicted deforestation and micro climate variables for the year 2030. By the year 2030, deforestation is illustrated to have escalated by $63.6 \%$ which will bring maximum temperature to $36.8^{\circ} \mathrm{C}$, minimum temperature $21.6^{\circ} \mathrm{C}$, PPT $0.29 \mathrm{~mm} / \mathrm{day}$, wind $2.90 \mathrm{~m} / \mathrm{s}$, relative humidity $63.6 \mathrm{kPa}$, solar output $27.3 \mathrm{MJ} / \mathrm{m}^{2} / \mathrm{day}$ and evapotranspiration to be $31.4 \mathrm{~mm} / \mathrm{day}$. Comparing these figures in Table 4 to the year 2018 (Table 2), forested area is predicted to suffer a reductionby $36.1 \%$, maximum temperature would likely rise by $8.15 \%$, minimum temperature increased by $0.88 \%$. Furthermore, rainfall is predicted to drop by $30.9 \%$, wind speed to drop by $3.65 \%$, relative humidity to decline by $8.6 \%$, solar output to decrease by $3.2 \%$ while evapotranspiration is expected to increase by $8.8 \%$.

The implication of these result for maximum and minimum temperature is the increase upon these variables that will spoil human health which leads to illness such as heat waves, meningitis, typhoid, malaria among others. This result is suitable towards Daramola et $a l$. , (2015) that stated in Ilorin, the forest have been put towards to construction areas and grassland in most areas between 1972-2014 in Ilorin. Temperature up surge might also affected agricultural activities leading to a decrease of crop yield. Hence, decrease in yield of 
crops means disturbing food security within the area. Trees should be planted in the area to reduce temperature and people could make benefit of it as the shade upon afternoon heat, thus it would help people in the sense physiological comfort. Temperature increase might also altered rainfall season in the area. There is an increase in temperature variation due to forest loss. This tends to lead to an increase towards mean and maximum upon air temperature compared to carbon dioxide emissions from land-use change that resulting to significant amount of heat (Alkama \& Cescatti, 2016).

Furthermore, the loss of shade may result inheat index escalation to over $9{ }^{\circ} \mathrm{C}$. This occurs as forests environment, evapotranspiration reduces sensible heat and means a much more frigid environment could be created (Bright et al., 2017; Ellison et al., 2017; Wolff et $a l ., 2018)$. The microclimate has been greatly affected, since high temperature changes due to land use patternis shifting. Land surface temperature analysis shows an upsurge in urban land area temperature was due to reduction of forested areas and grasslands. The decrease will possibly disturb water security which involves accessibility, availability and quality in the area. Decrease of rainfall affects the water table constribution towards residents within the area.

Decrease in wind speed may interrupting pollination in the area that leading to yield of crops decline. In term of human health, the drop of wind speed will reduce the spread of airborne diseases, means this proposes a positive effect on human health. Decrease in relative humidity can affect human skin, namely dryness of the skin. It could also affect crops in the area. Evapotranspiration increase would manage to increase the rainfall that may consequence in flooding which threatens life and properties. Hence, a crucial climate change by 2030 could be avoided (Fritts, 2018; Milman, 2018). This happens, since carbon mitigation can be achieved where there is vast proportion of forest cover and this would avoid the release of carbon dioxide as well as harnessing atmospheric carbon by the growing forest.

\section{Conclusion}

The study concludes that deforestation greatly influences the microclimate of Ilorin and occurs due to human's anthropogenic activities. These human activities are related to the conversion of land from forest to agricultural land. Furthermore, the use of agricultural land that is not under regulations will increase bare land. Deforestation has also led to climate change. Thereby, this study recommends public awareness and provide education for people to recognize and engage manners to avert and reduce the adverse environmental effect 
associated with deforestation and take appropriate actions to deal with it. Laws regulations should be enacted and enforced by government to reduce the nature and to limit extent of the destruction of the forest. Penalties should also be put in place for violators.

\section{Conflict of Interest}

The authors declare that there is no conflict of interest with any financial, personal, or other relationships with other people or organizations related to the material discussed in the article.

\section{References}

Adeleke, E. A., Olabode, A. D., \& Oni, A. E. (2017). Weather conditions and crimes prevalence in Ifako- Ijaye (Lagos State, Nigeria). Varstvoslovje, 19(4), 363-384.

Ajadi, B. S., Adaramola, M. A., Adeniyi, A., \& Abubakar, M. I. (2016). Effect of effluents discharge on public health in Ilorin Metropolis, Nigeria. Ethiopian Journal of Environmental Studies and Management, 9(4), 389-404. https://doi.org/10.4314/ejesm.v9i4.1.

Alkama, R., \& Cescatti, A. (2016). Climate change: Biophysical climate impacts of recent changes in global forest cover. Science, 351(6273), 600-604. https://doi.org/10.1126/science.aac8083.

Bender, R., Ziegler, A., \& Lange, S. (2007). NCSS Statistical Software : Chpater 305 Multiple regression. Utah : Ncss, Llc, (pp. 1-63).

Bright, R. M., Davin, E., O’Halloran, T., Pongratz, J., Zhao, K., \& Cescatti, A. (2017). Local temperature response to land cover and management change driven by non-radiative processes. Nature Climate Change, 7(4), 296-302. https://doi.org/10.1038/nclimate3250.

Chakravarty, S. K. S, Ghosh, C. P. S., \& Shukla, A. N. Dey, G. S. (2012). Global Perspectives on Sustainable Forest Management. Rijeka : Intechopen, (pp. 1-29).

Chapman, S., Syktus, J., Trancoso, R., Salazar, A., Thatcher, M., Watson, J. E. M., ... Mcalpine, C. A. (2020). Compounding impact of deforestation on Borneo's climate during El Nie\&ntild;o events. Environmental Research Letters, 15(8), 084006. https://doi.org/10.1088/1748-9326/ab86f5.

Daramola, J., Aro, J. K., \& Daramola, E. L. (2015). An Assessment of the Impact of Deforestation on Climate Change: Case Study of Ilorin, Kwara State. Paper presented at 56 th Annual Conference of Association of Nigeria Geographers (ANG). Lagos, Nigeria.

Dias, L. C. P., Macedo, M. N., Costa, M. H., Coe, M. T., \& Neill, C. (2015). Effects of land cover change on evapotranspiration and streamflow of small catchments in the Upper Xingu River Basin, Central Brazil. Journal of Hydrology: Regional Studies, 4, 108-122. doi:10.1016/j.ejrh.2015.05.010. 
Ellison, D., Morris, C. E., Locatelli, B., Sheil, D., Cohen, J., Murdiyarso, D., Gutierrez, V., Noordwijk, M. van, Creed, I. F., Pokorny, J., Gaveau, D., Spracklen, D. V., Tobella, A. B., Ilstedt, U., Teuling, A. J., Gebrehiwot, S. G., Sands, D. C., Muys, B., Verbist, B., ... Sullivan, C. A. (2017). Trees, forests and water: Cool insights for a hot world. Global Environmental Change, 43, 51-61. https://doi.org/10.1016/j.gloenvcha.2017.01.002.

FAO. (2020). The State of the World's Forests 2020, Forest, Biodiversity and People. Rome : FAO. https://doi.org/10.4060/ca8642en.

Fonge, B. A., Tabot, P. T., Bakia, M. A., \& Awah, C. C. (2019). Patterns of land-use change and current vegetation status in peri-urban forest reserves: the case of the barombi mbo forest reserve, cameroon. Geology, Ecology, and Landscapes, 3(2), 104-113.

Fritts, R. (2018). Tropical deforestation now emits more CO2 than the EU. Mongabay, October. https://news.mongabay.com/2018/10/tropical-deforestation-now-emits-moreco2-than-the-eu/.

Hardwick, S. R., Toumi, R., Pfeifer, M., Turner, E. C., Nilus, R., \& Ewers, R. M. (2015). The relationship between leaf area index and microclimate in tropical forest and oil palm plantation: Forest disturbance drives changes in microclimate. Agricultural and Forest Meteorology, 201(1), 187-195. https://doi.org/10.1016/j.agrformet.2014.11.010.

Ifabiyi, I. P., \& Ashaolu, E. D. (2014). Analysis of the Impacts of Rainfall Variability on Public Water Supply in Ilorin, Nigeria. Journal of Meteorology \& Climate Science, 11(1), 18-26.

Iroye, K. A. (2017). Correlating Pattern of River Discharge with Degree of Urbanization in Sub-Catchments of River Asa In Ilorin, Nigeriatle. Ethiopian Journal of Environmental Studies \& Management, 10(2), 251-261.

Jucker, T., Jackson, T. D., Zellweger, F., Swinfield, T., Gregory, N., Williamson, J., ... Coomes, D. A. (2020). A Research Agenda for Microclimate Ecology in HumanModified Tropical Forests. Frontiers in Forests and Global Change, 2. https://doi.org/10.3389/ffgc.2019.00092.

Kumari, R., Banerjee, A., Kumar, R., Kumar, A., Saikia, P., \& Khan, M. L. (2019). Deforestation in India: consequences and sustainable solutions. In Forest Degradation Around the World. Rijeka : IntechOpen.

Li, Y., Zhao, M., Mildrexler, D. J., Motesharrei, S., Mu, Q., Kalnay, E., Zhao, F., Li, S., \& Wang, K. (2016). Potential and actual impacts of deforestation and afforestation on land surface temperature. Journal of Geophysical Research, 121(24), 14372-14386. https://doi.org/10.1002/2016JD024969.

McAlpine, C. A., Johnson, A., Salazar, A., Syktus, J., Wilson, K., Meijaard, E., ... Sheil, D. (2018). Forest loss and Borneo's climate. Environmental Research Letters, 13(4), 044009. https://doi.org/10.1088/1748-9326/aaa4ff.

Milman, O. (2018). Scientists say halting deforestation ' just as urgent ' as reducing emissions. The Guardian, 4-6. http://www.theguardian.com/environment/2018/oct/04/climate-deforestation-global-warming-report. 
Nunes, L. J. R., Meireles, C. I. R., Gomes, C. J. P., \& Ribeiro, N. M. C. A. (2020). Forest contribution to climate change mitigation: Management oriented to carbon capture and storage. Climate, 8(2), 1-20. https://doi.org/10.3390/cli8020021.

Odoemene, A. (2017). Climate change and land grabbing. Research Handbook on Climate Change and Agricultural Law, 423-449. https://doi.org/10.4337/9781784710644.

Prevedello, J. A., Winck, G. R., Weber, M. M., Nichols, E., \& Sinervo, B. (2019). Impacts of forestation and deforestation on local temperature across the globe. PLOS ONE, 14(3), 1-11. https://doi.org/10.1371/journal.pone.0213368.

Senior, R. A., Hill, J. K., Benedick, S., \& Edwards, D. P. (2018). Tropical forests are thermally buffered despite intensive selective logging. Global Change Biology, 24(3), 1267-1278. https://doi.org/10.1111/gcb.13914.

Su, G. S., Macawile, J., Villarino, A., Agapito, J., \& Gomez, N. (2011). Recognizing Local People's Perceptions Towards Deforestation in Quezon Province, Philippines. Environmental Research Journal, 5(3), 131-135. https://doi.org/10.3923/erj.2011.131.135.

Tchatchou, B., Sonwa, D. J., Ifo, S., \& Tiani, A. M. (2015). Deforestation and forest degradation in the Congo Basin: State of knowledge, current causes and perspectives. Bogor: $C I F O R$.

USEPA. (2017). Learn About Heat Islands Heat Island Effect. https://www.epa.gov/heatislands/learn-about-heat-islands.

Wolff, N. H., Masuda, Y. J., Meijaard, E., Wells, J. A., \& Game, E. T. (2018). Impacts of tropical deforestation on local temperature and human well-being perceptions. Global Environmental Change, 52(July), 181-189. https://doi.org/10.1016/j.gloenvcha.2018.07.004.

WRI. (2010). From Copenhagen To Cancun : Forests and REDD. World Resources Institute. https://www.wri.org/blog/2010/05/copenhagen-cancun-forests-and-redd.

WRI. (2020). FORESTS Sustaining forests for people and planet. World Resource Institute. https://www.wri.org/our-work/topics/forests.

WWF. (2017). Forest Habitat, World Wide Fund. World Wildlife Fund. https://www.worldwildlife.org/habitats/forest-habitat. 